\title{
Complete Streets and Implementation in Small Towns
}

\author{
Diane M. Calloway, Ardeshir Faghri \\ Department of Civil and Environmental Engineering, University of Delaware, Newark, DE, USA \\ Email: faghri@udel.edu
}

How to cite this paper: Calloway, D. M., \& Faghri, A. (2020). Complete Streets and Implementation in Small Towns. Current Urban Studies, 8, 484-508.

https://doi.org/10.4236/cus.2020.83027

Received: August 25, 2020

Accepted: September 21, 2020

Published: September 24, 2020

Copyright (c) 2020 by author(s) and Scientific Research Publishing Inc. This work is licensed under the Creative Commons Attribution International License (CC BY 4.0).

http://creativecommons.org/licenses/by/4.0/

\begin{abstract}
As our transportation networks and infrastructure have become more and more focused on automobiles, we have seen a number of problems, such as traffic congestion, environmental damage, and health concerns. To combat this issue, there is a growing movement towards complete streets, which allow equal access for all modes of transportation. A large portion of this article extensively explores the concept of complete streets from both an international and domestic (US) perspective. In doing so, we identify many different ways cities across the world have implemented complete streets or increased transportation equity, which has led to a multitude of societal benefits. However, the report also notes that most of these improvements have been made in urban settings, where it is easier to implement complete streets due to existing infrastructure, smaller distance between destination places, and ample financial resources. Complete streets are much more difficult to implement within small towns in rural settings, which is problematic since these residents often have the least opportunity to use active transportation modes. The final section of the report identifies these challenges within rural communities, offers suggestions regarding complete street planning in these areas, and provides an in-depth process for implementing complete streets in small towns.
\end{abstract}

\section{Keywords}

Complete Streets, Transportation Equity, Small Towns

\section{Introduction}

Gone are the glory days of suburbia. Our nation's youth no longer desires to move outside the city centers like we have over the last 60 years. Today's movement of people is heading back into our vibrant and diverse city centers. Real estate and economic trends are showing a reversal of movement back to areas of 
dense residential and commercial mixed use. Today's generation want to be able to walk or bike from home to work, to shop and back. Many are choosing not to even get a driver's license. They are cognizant of their health and want to live in diverse and thriving downtowns filled with commercial and entertainment destinations. Meanwhile, small towns across America are struggling with vacant buildings and dreams of being what they once were. The way to bring together the desire to live in a connected complete community and mix it with an economic resurgence of small towns in rural America is to update the transportation system that links these origins to their destinations; small towns and rural communities need to implement complete streets.

Complete streets are defined as roads that allow all modes of transportation without giving preference to one of the modes over others. In recent years, transportation networks have become more and more auto biased, giving preference to automobiles over other forms of transportation. As the transportation infrastructure becomes more auto oriented, active modes like walking, biking, or transit are devalued and discouraged, and various new research studies indicate various health and traffic related problems caused by auto oriented roadways. A comparison between auto oriented and complete streets can be seen in Figure 1 .

The red lines in Figure 1 are indicative of an auto-focused street plan and design with little to no connection with transit, pedestrian and bicycle facilities, whereas the blue lines represent a more comprehensive treatment of urban settings with equal consideration for autos, transit users, pedestrians and bicyclists. Today, reversing the trend of increased auto usage is difficult, but complete street is one of the best ways to address this problem, as converting existing streets into complete streets is much easier than designing completely new transportation networks.

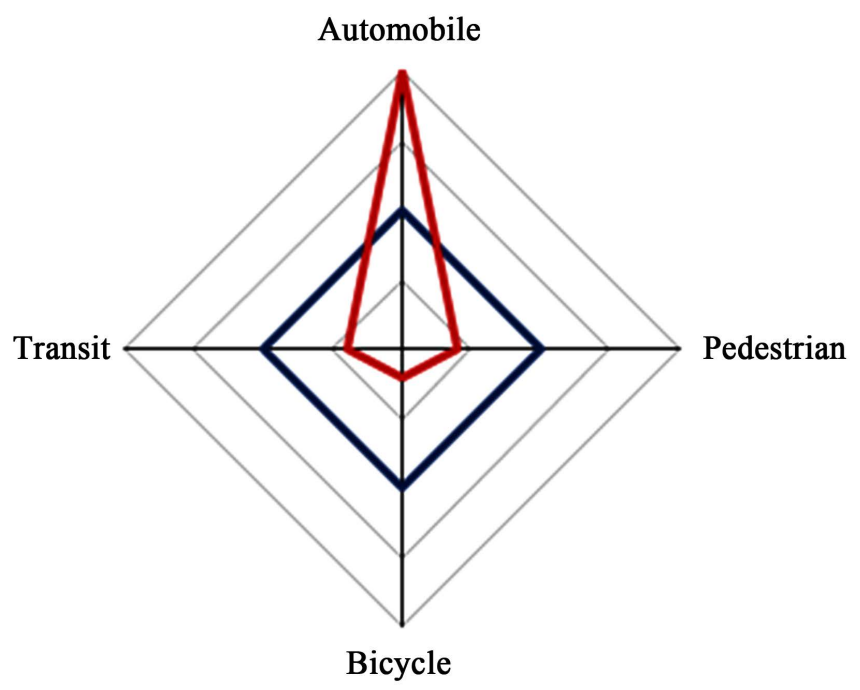

Complete Street $\longrightarrow$ Auto-Oriented Street

Figure 1. Complete vs. auto oriented streets (Kingsbury, Lowry, \& Dixon, 2011). 


\section{International History}

Around the globe, examples of Complete Streets can be found in many major populated areas. From Europe to Asia to North America, several countries are mastering the method of equal access of transportation to all users. Europe is ahead of the world with their resistance to an automobile centric transportation plan. The cities and towns of Europe have existed for centuries and have thrived on being walkable and friendly to all transportation users. Many European cities and towns feature cobblestone streets, street lighting, shops and boutiques dotting the edges of the rights-of-way, and cafés with chairs and tables going to the edge of the elevated curbside. These inviting spaces promote walking and bicycling. The cost of gasoline in Europe also motivates more residents to find alternate forms of transportation. Asia is known for its public squares and large walkable downtowns. Evolina Ozola summarized it well in her TEDxRiga talk entitled, "Architect's Hands: How Can We Design Better Streets" when she summarized that a complete street is "Where everyone young, healthy, and financially secure as well as those whose income is modest and whose movements are limited can equally take part in mobility and in social life." (TEDxTalks, 2015). Because of centuries of experience, countries all over the world have a good grasp of what works and how their cities and towns can thrive in changing times and provide transportation equity. In the following section, many international cities that are known for their complete streets will be highlighted.

\subsection{International Examples}

\section{Amsterdam, Netherlands}

The first example of mastering complete streets is the city of Amsterdam in the Netherlands. Amsterdam is a bustling city filled with residents and tourists which meander along its canal lined streets. When travelling there, tourists are generally shocked by the lack of vehicles and the number of bicycles which traverse the city. In addition to thousands of bicycles, there are accommodations for pedestrians, metro, bus service, canal boat, and small motorized vehicles. Bicycling is prevalent, but there is availability of all modes of transportation within the city. In the Netherlands, bicycling is a way of life, the preferred mode of transportation. The Dutch are known world-wide for their use of bicycling as a primary method of travel. The volume of bicycle parking is overwhelming, but when one considers that more than 8 bicycles can park in the same square footage as one vehicle, the area is better served to accommodate more travelers. An example of bicycle parking availability is shown in Figure 2 below. The Dutch have also successfully linked public transportation hubs like Amsterdam Central train station to several modes of travel to get into the city. Amsterdam Central Station main train station is the real heart of the city: central not only by the name, but also as the biggest public transportation transfer spot, serving not only visitors to Amsterdam, but also city inhabitants. Every day, thousands of people go through the Amsterdam Central Station. 


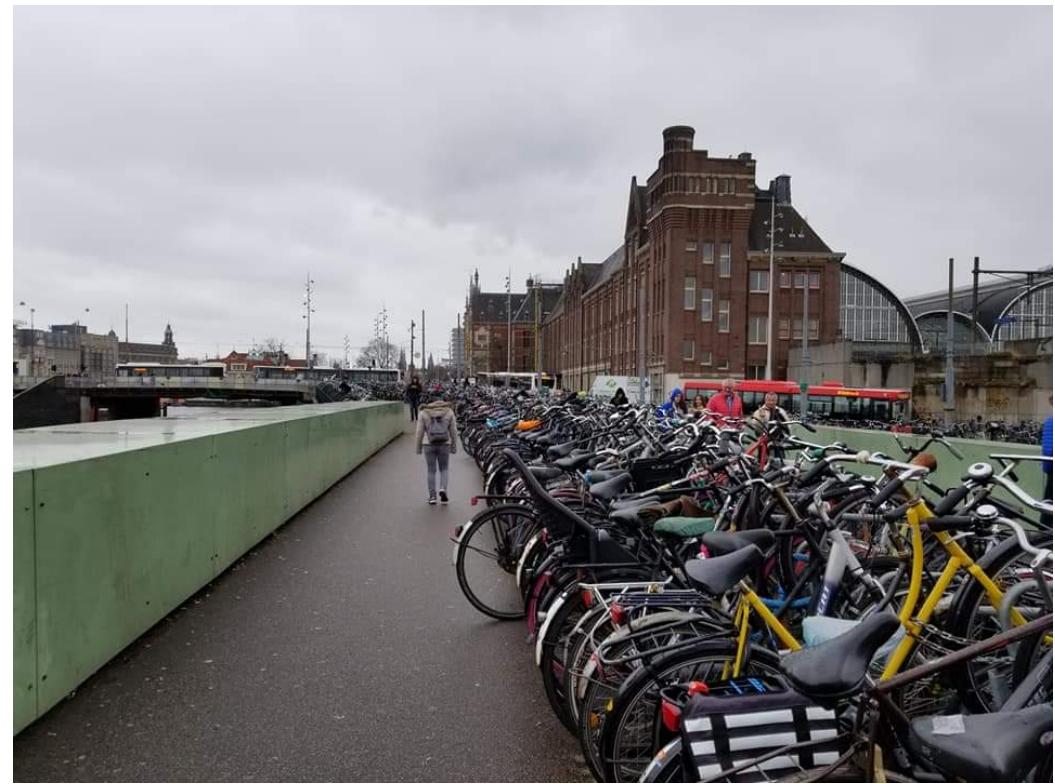

Figure 2. Bicycle parking near Amsterdam central train station (Calloway, 2018).

Final stops of several lines of city trams and buses are located here, as well as waterfront stations of city ferry lines taking cars and passengers to Amsterdam North (Amsterdam Noord). It is also here, that a main Amsterdam Tourist Office is based, as well as departure quays for the tourist boats cruising around the city canals.

This complete street characteristic is notably one to replicate in all areas.

\section{Lisse, Netherlands}

In the Netherlands, there is a smaller city named Lisse to the southwest of Amsterdam that has a downtown shopping district where vehicles are not permitted (unless making deliveries) and business is thriving. In this city, if one travels along Kanaalstraat as a tourist, they will see that unlike most US city streets, this street is filled with planters and vegetation, proper lighting, and is impeccably clean. Families with young children, strollers, bicycles, and scooters are frequent, and there are no cars. One can stop to have ice cream while sitting in café chairs in the street and converse with family, friends and passersby. While this road diet would be incredibly difficult to accomplish in the US and not create a truly complete street, it would create a more dynamic, safe, and thriving downtown destination. This removal of the automobile can be highly successful if there is connectivity in the adjacent network. There must be ample parking and destinations for people to visit to draw them into this car-les street. Retail companies must be given a way to deliver their supplies, and there should be ample signing and guidance to make it clear what is expected in this district. With all these conditions present, the benefits can be duplicated in small and large towns and cities to establish a safe, unpolluted, interactive commercial destination. A street view and overhead view of Kanaalstraat is shown in Figure 3 and Figure 4 respectively below. 


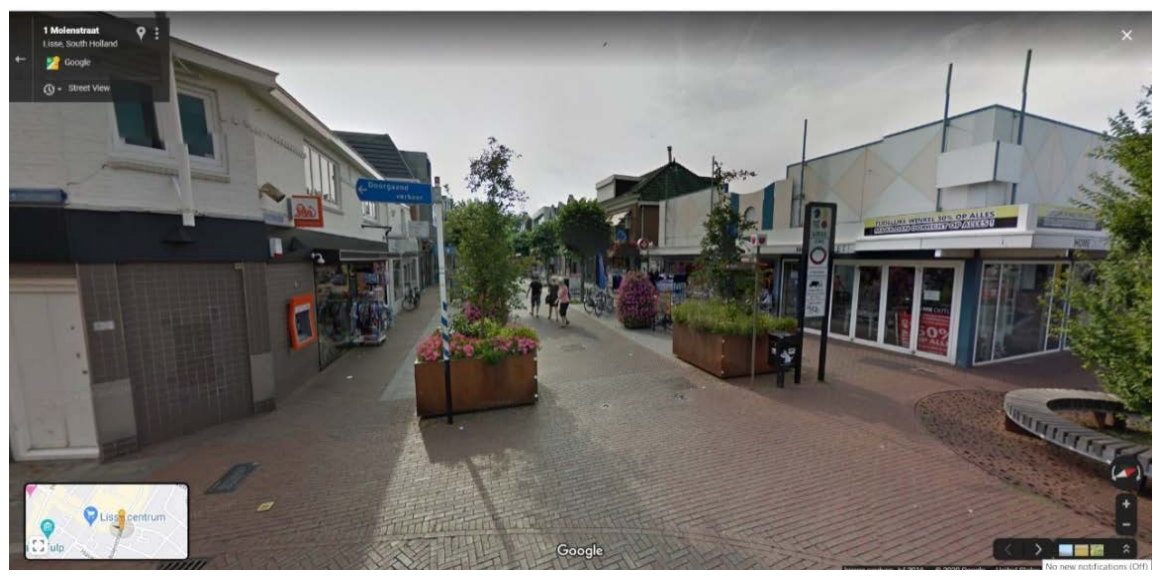

Figure 3. Google street view of Kanaalstraat in Lisse, Netherlands (Google, n.d.a).

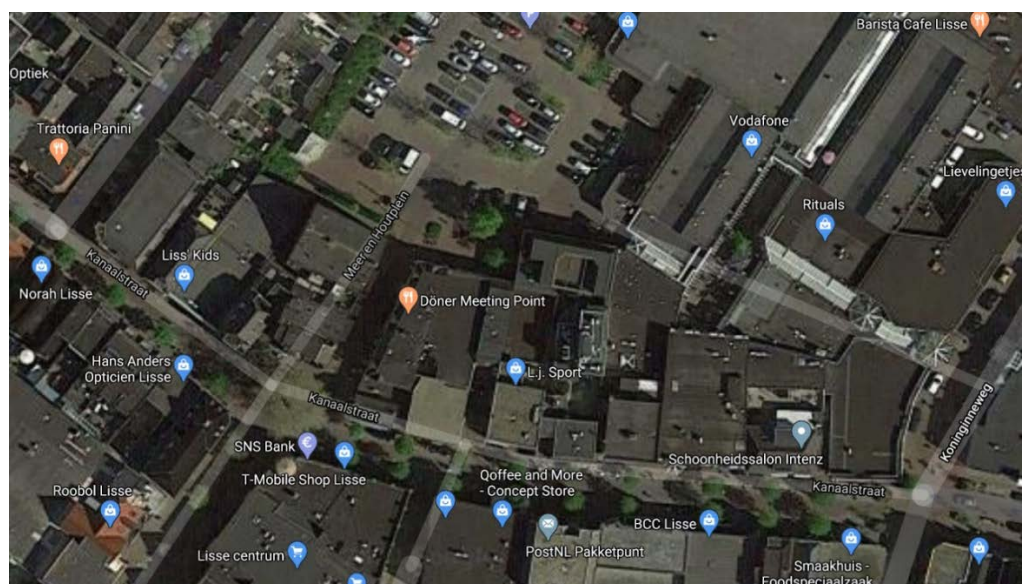

Figure 4. Google maps image of Kanaalstraat in Lisse, Netherlands (Google, n.d.b).

\section{London, England}

London, England is another bustling European city, known for its architectural and civil engineering structures such as Big Ben, Tower Bridge, and Buckingham Palace. In addition to these tourist destinations, London is filled with examples of complete streets. What makes them easily traversable and inclusive is the consistent use of colored pavements to mark areas reserved for bicycles and areas reserved for buses or other modes of transportation, as seen in Figure 5.

The photograph shows an entire lane painted green to designate a multi-modal facility, and in the background one can see red pavement coloring designating the area along the curbing reserved for bus and transit use. This relatively low-cost painting method brings attention to the space, and if used consistently internationally, it becomes familiar to all those travelling. This practice is worth repeating in any complete street application to build global conformity. Other famous streets in London such as Oxford (one of the most iconic street names in UK especially among shoppers), Abbey Road and Piccadilly are also among excellent examples of complete streets with modern and efficient transit, bicycle and pedestrian facilities. 


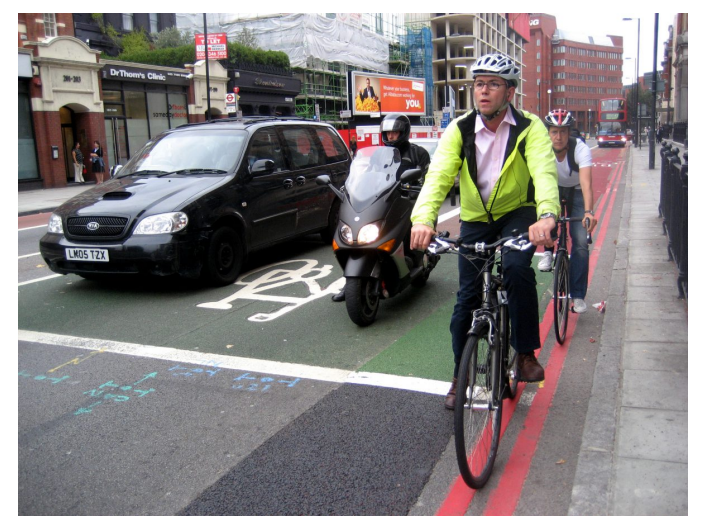

Figure 5. A complete street in London, England (Kodransky, n.d.).

\section{Copenhagen, Denmark}

Next, in the city of Copenhagen, Denmark, bicycling is also a favored mode of transportation. According to Barbara McCann's 2010 article on Smart Growth America, “...in Copenhagen, 55\% of all trips are made on bicycles" (McCann, 2010). Copenhagen highlights both a love of bicycling and the many ways public spaces can be used when vehicles are removed. Take for example Strøget Street, shown in Figure 6 below. According to the Project for Public Spaces, "Located in the center of the old city of Copenhagen, which has been labeled the 'most livable city in the world,' Strøget is one of the oldest and longest pedestrian streets in Europe." (Project for Public Spaces, 2015). Though this concept is likely to meet with great criticism and skepticism, the removal of vehicles from targeted areas of a community can be a tremendous draw to tourism and non-motorized modes of travel. It should be noted that by removing the vehicle, the street will no longer be complete, but if used sparingly, the affect will draw the modes less represented on most streets within a community. This idea of removing the vehicle, turns what used to be a link in a transportation plan and converts it to a destination node.

\section{Nuremberg, Germany}

Similar to Denmark, Germany has also attempted to pedestrianize areas for the benefit of the inhabitants. In Nuremberg, citizens sought to improve air quality. For the last four and a half decades, the city has been shifting from automobile-dominated roadways to focusing on the pedestrian movements, and the results they have witnessed have proven effective as stated by the European Commission:

"On four occasions when heavily congested roads were closed to cars in the city, some of the traffic appears to have 'evaporated'. Traffic volumes on the other streets grew by only $20 \%-29 \%$ of the traffic originally on the then closed roads. At the same time, the decline in visitors predicted by retailers did not occur; in fact, rather the opposite occurred in the newly pedestrianized streets... Significant improvements in air quality have been achieved" (European Commission, 2004). 


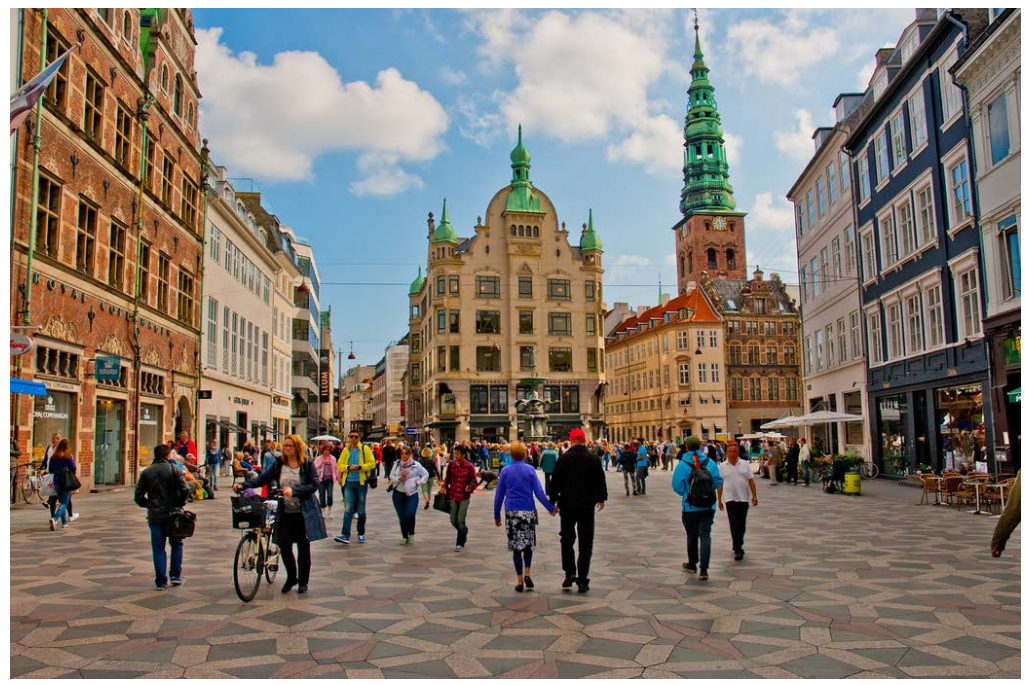

Figure 6. Støget street in Copenhagen, Denmark (City Clock Magazine, 2013).

The City of Nuremberg recouped both air quality and reduced congestion by limiting the automobile from portions of their city. Many towns and cities across the globe could also implement this policy on select areas of their transportation network.

\section{Zurich, Switzerland}

The city of Zurich in Switzerland is a great example for the use of transit. In his book Street Smart. The Rise of Cities and the Fall of Cars, Samuel I. Schwartz states, "Zurich is probably the most transit-friendly city in the world." (Schwartz \& Rosen, 2015). Schwartz, who is an avid proponent of reducing our dependency on the personal vehicle, highlights that Zurich has street cars, trolleybuses, motor buses, passenger ships, ferries, commuter trains and funiculars. To make transit a self-supporting lucrative venture, it must attract all classes of people, have clean and safe environments, and be on-schedule. Schwartz also mentions that all transit needs "...reliability and frequency... a usefully frequent network is one that stops at a convenient transit node at least every fifteen minutes, and ideally even more often" (Schwartz \& Rosen, 2015). Zurich's Public Transport is used by many since it excels in all these aspects. Tourists can buy the Zurich Card for either 24 or 72 hours to use any mode of transit within the City with that one purchase (Zurich Tourism, n.d.). Transit can be offered in many forms depending on the landscape of the area. The inclusion of transit should always be considered when transforming a vehicular right-of-way to a complete street because it can be convenient and cost effective, thereby providing transportation equity to all.

\section{Barcelona, Spain}

In the Spanish city of Barcelona, a traveler can experience many of the characteristics discussed and more. Schwartz, who also highlighted Barcelona in his book, describes Barcelona as a model city for traffic calming. He states that 70 percent of crashes can be reduced, and 20 percent of walking can be increased by 
traffic calming (Schwartz \& Rosen, 2015). Traffic calming has been a tool used for decades to discourage use of streets and corridors by through traffic. There are many forms of traffic calming which include, but are not limited to, gateways and pavement colorations, rumble strips, mumble strips, rumble areas, jiggle bars, build-outs, road narrowing, center islands, chicanes (lane shifts), speed cushions, speed tables and road humps (Wright, Ashford, \& Stammer, 1998). According to Wright et al., traffic calming has 4 primary objectives:

- To reduce the number and severity of accidents;

- To enhance the amenity of the urban or built-up rural environment;

- To remove unnecessary trucks and automobiles by encouraging them to use faster, easier routes;

- To create road conditions in which drivers drive with great care at low speeds. Traffic calming slows the pace of vehicular traffic so that pedestrians, bicyclists and all other non-motorized travelers feel safe to utilize the same space or nearby area, promoting street use by all modes.

There are countless additional European examples of complete streets and shifting away from car-dependency, but other countries around the world are also finding creative ways to mix modes of travel so that all can have an equal opportunity for transportation.

\section{Tokyo, Japan}

In Japan, where there is a relatively high average age in the population, they are investing in infrastructure to make transportation and all other conveniences available to those with disabilities. The Law on the Elimination of Discrimination against Persons with Disabilities was enacted in 2013. This promoted both private and governmental agencies to improve infrastructure and services so all would have equal access (Brasor, 2016).

Japanese officials also began to separate transportation modalities by speed as opposed to by class or type (Price, 2019). An example of such a street is shown in Figure 7 below. Figure 7 shows a facility that is used only for pedestrians and tricycles. This contrasts with how most countries address complete streets. Motorized vehicles are permitted on some of these streets, but because of their narrow width and traffic calming measures, it is not comfortable to drive fast. Therefore, modes such as walking and biking are easily mixed in the flow.

The typical complete street has a designated area for cars, a lane for bicycles, and another lane for pedestrians and tricycles, as shown in Figure 7. This historical separation of modes of travel leads to the need for an incredible amount of right-of-way and requires a two-way street to be 70 feet in width. In most towns, the average right-of-way is only 30 - 50 feet, so one or more of the modes must be sacrificed to provide for the others. In the last 50 years, the priority went to the car. Since Tokyo is so densely populated, land is at a premium, and every square inch is utilized. This principle of dividing streets by speed is an excellent strategy for providing equity for all transportation modes in small towns where rights-of-way are typically narrow with limited set back of structures. 


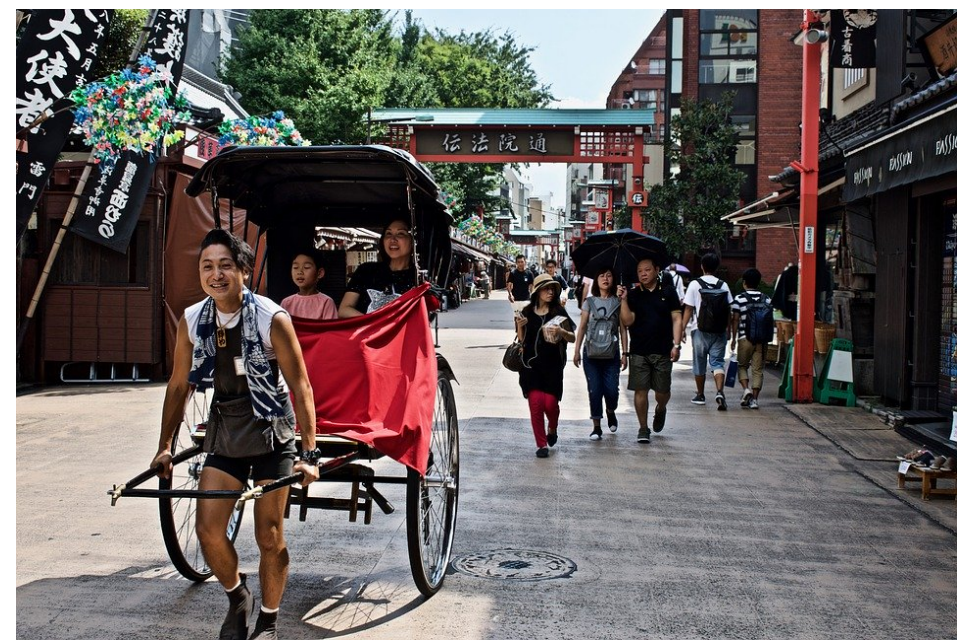

Figure 7. Street in Tokyo, Japan designated for slower traffic such as pedestrians and tricycles (Dylanagonzales 2011, 2019).

Furthermore, research has shown that speed of vehicular traffic correlates to safety. The higher the vehicular speed, the higher the probability of mortality during a collision (FHWA, 2009). Additionally, the higher the age of the pedestrian the higher the probability of mortality. According to FHWA data below in Table 1, the probability of pedestrian fatality dramatically increases between 20 and $30 \mathrm{mph}$ for all age groups.

It is evident that speed grouping is safer and more comfortable by those travelling. If there is a younger or less experienced rider, they would prefer to be grouped with those travelling at approximately the same velocity, while more advanced riders would be comfortable at higher speeds with vehicles. The Japanese have created an inclusive and comfortable mixing of travel modes that would do well in small towns and rural communities, especially those with agricultural and horse and buggy travelers.

\section{Beijing, China}

When researching benefits based on implementing complete streets, Beijing, China proved that benefits can be experienced in as little as a month. A study conducted by $\mathrm{Yi} \mathrm{Li}$ on the alternative transportation methods used during the 2008 Summer Olympics in Beijing observed, "the average number of outpatient visits for asthma was 12.5 per day at baseline and 7.3 per day during the Olympics-a 41.6\% overall decrease" (Li et al., 2011).

They concluded that along with "good" weather conditions, efforts to reduce traffic congestion in Beijing during the Olympic Games were associated with a prolonged reduction in air pollution and significantly lower rates of adult asthma events (Li et al., 2011). The data collected and analyzed over the course of those few months shows the dramatic impact that complete streets initiatives, which reduce motorized vehicle traffic, can make to our health. When implementing complete streets anywhere in the world, this data needs to be collected and shared to promote the positive benefits of this design methodology. 
Table 1. Probability of pedestrian death vs. vehicle speed (FHWA, 2009).

\begin{tabular}{ccccc}
\hline $\begin{array}{c}\text { Vehicle } \\
\text { speed } \\
(\mathrm{mph})\end{array}$ & $\begin{array}{c}\text { Probalility of } \\
\text { pedestrian } \\
\text { fatality }(\%)^{*}\end{array}$ & $\begin{array}{c}\text { Probalility of } \\
\text { pedestrian } \\
\text { fatality age }=14(\%)^{* *}\end{array}$ & $\begin{array}{c}\text { Probalility of } \\
\text { pedestrian fatality } \\
\text { age } 15 \text { to } 59(\%)^{* *}\end{array}$ & $\begin{array}{c}\text { Probalility of } \\
\text { pedestrian } \\
\text { fatality age }=60(\%)^{* *}\end{array}$ \\
\hline 20 & 5 & 1 & 1 & 3 \\
30 & 45 & 5 & 7 & 62 \\
40 & 85 & 16 & 22 & 92 \\
\hline
\end{tabular}

\section{Canada}

If implementing complete streets can make us healthier, can it also make us happier? According to Charles Montgomery, a Canadian urbanist and author of Happy City. Transforming Our Lives through Urban Design, states that “...the happy city is a social city above all." He went on to say that:

“... Social connections correlate really strongly with economic growth. So if we care about having a happy, resilient, healthy and wealthy society we really should care about building social connections. And I use that word building on purpose because I also discovered that the systems and forms of our cities influence how we feel and how we treat each other. So our roads, our buildings, our neighborhoods, our parks, our sidewalks...these are emotional infrastructure." (TEDxTalks, 2014).

Here in the United States, the University of Minnesota Center for Transportation Studies is researching how transportation modes effect happiness. Their initial studies indicate that biking is the happiest form of transportation and duration of the overall trip plays a large role in our perceived happiness (University of Minnesota, 2017). Health and happiness are the benefits of the international examples of complete streets.

\subsection{Summary of International Examples}

Cities across the globe have thrived not only because of their history and cultural draw to tourists, but in the timeless characteristic of being walkable and traversable by all. In Europe, the inclusiveness and heavy utilization of bicycling, transit and public spaces brings people together. In Asia and Canada, the benefits of complete streets can be seen in the mobility of all persons regardless of age or ability and in making them happier and healthier. In the next section, examples of complete streets in the United States are presented. The complete streets movement is growing in the United States in part by following the examples of our international counterparts.

\section{Domestic History}

In the US, complete streets policies developed as a response to the increasing car-centered transportation networks that were developing in the early 2000s. The term "complete streets" was first used by America Bikes in 2003, who were 
creating new policy initiatives to provide equal rights and safety for travelers using all transportation modes. The movement really picked up with the formation of the National Complete Streets Coalition in 2005, which consisted of members such as the American Planning Association, America Bikes, Smart Growth America, and others. Over the next few years, hundreds of complete streets policies were adapted by cities and towns all over the country (Zehngebot \& Peiser, 2014). Today, efforts to convert existing streets into complete streets is increasing to combat the many adverse effects of an auto-centered society.

However, a major challenge to implementing complete streets occurs in rural communities, where there are few amenities and major destinations lie far outside the town limits. Growing up in the United States, you are more likely to travel by modes other than a personal vehicle if you live in an urban environment than in a rural area. One study found that residents in rural communities have much lower opportunities for active transportation modes such as walking and biking, and this is linked with significantly lower physical activity for rural residents when compared to urban and suburban residents (Park, Eyler, Tabak, Valko, \& Brownson, 2017). In rural areas, walking and bicycling are typically done for entertainment and/or exercise and not likely done as a mode of transportation.

\subsection{Comparison to International Travel}

Though the US is slowly updating streets and corridors to be complete for all travel modes, we have significant room for improvement when comparing ourselves internationally. As illustrated in the travel mode breakdown in Figure 8, 2017 National Household Travel Survey data reports that in the US, only 1\% of transportation modes used to make a trip by respondents was done so walking or biking. Transit trips, comprised of boat/ferry/water taxi, airplane, subway/elevated/light rail/street car, Amtrak/commuter rail, City-to-city bus (Greyhound, Megabus), Private/Charter/Tour/Shuttlebus, Paratransit/Dial-a-ride, Public or commuter bus, and school buses, accounted for roughly $21 \%$. Vehicular trips, calculated by combining rental cars, taxi/limo, RV, motorcycle, golf cart, pickup, van, SUV and car, were almost $77 \%$.

Comparing the number of trips we in the US take by active transportation modes (walking and bicycling) to the United Kingdom (UK), Germany (GER), Denmark (DK) and the Netherlands (NL) we are far behind. As seen in Figure 9 below, the US is last when comparing data individually by mode and also collectively by overall totals. Focusing on our youngest citizens, US children between the ages of 5 and 15 spend $18 \%$ of their trips using active modes of transportation, whereas in the Netherlands, children between the ages of zero and 17 use active transportation $64 \%$ of the time. That is over 3.5 times the US rate. When comparing this data to health trends such as BMI, the data correlates in that countries using active modes of transportation are far healthier. 


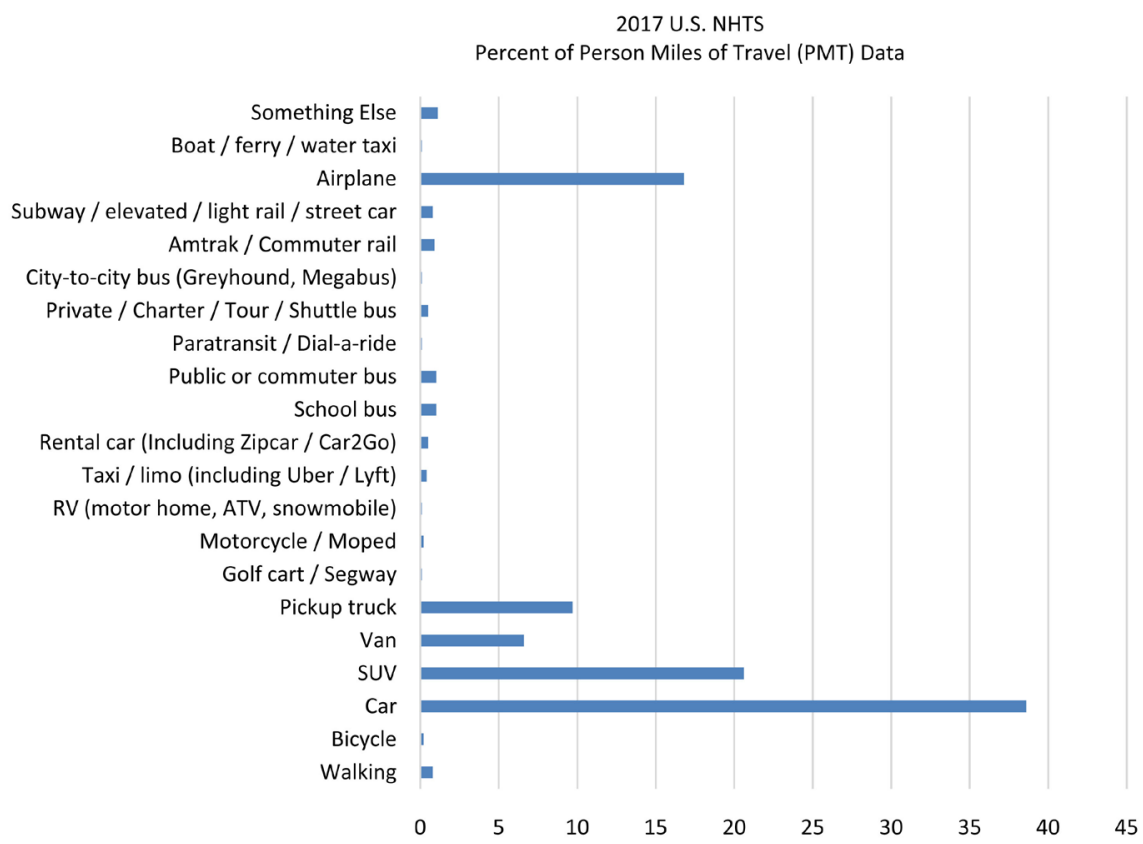

Figure 8. Modes of travel in US by percent (National Household Travel Survey, 2017).

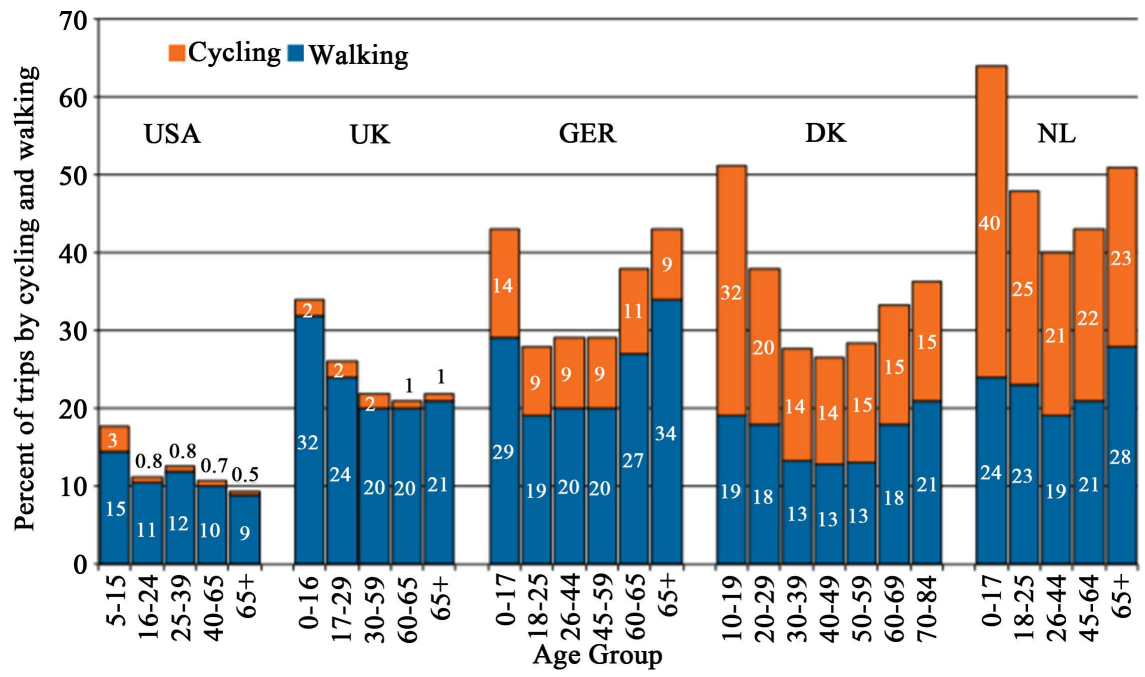

Figure 9. Comparison of trips taken by cycling and walking (Buehler \& Pucher, 2012).

Though the US is catching up with the rest of the world in the amount of daily active travel, there are terrific examples domestically to help serve as models for future complete streets. The movement toward making streets more inclusive to all began in isolated areas around the country. In cities like San Francisco, Pasadena, Chicago, and Portland, local officials proactively made transportation decisions in certain areas of their cities to put the focus from cars to all modes (Schwartz \& Rosen, 2015). There has also been a nationwide push for the implementation of complete streets by organizations such as the National Complete Streets Coalition. They have published numerous fact books, guides and literature intended to help communities establish complete streets policies and 
practices in their locations (Smart Growth America, n.d.).

\subsection{Domestic Examples}

\section{New York City}

New York City is one of the most visited cities in the world and is an economic center of the country filled with businesses and tourist destinations. Over the last 80 years, transportation officials have learned many methods to manage the daily volume of people that travel within the city. One of the icons of New York City transportation is Samuel I. Schwartz, who was mentioned earlier in the section on Zurich. In his design of the transportation for the proposed Barclays Center in the Brooklyn, it was believed that structure could not be built due to the limited land available and the incredible need for parking to accommodate the venue. But in thinking creatively, officials incentivized the use of ulterior modes of transportation. They ended up getting more than $75 \%$ to use metro, bicycle or other modes instead of their car. On average, only 120 spots out of the completed 541 parking spaces are used. Even at the biggest events the venue hosts, they only use about half of them (Schwartz \& Rosen, 2015). They did this by communication with stakeholders of their options to travel to the stadium. They provided informational outreach and reduced-price parking for carpooling and parking at remote lots that were serviced by free shuttles. This incident suggests that finding a way to draw people out of their cars and limit parking is a way to help any community's streets become complete.

\section{San Francisco}

The northern California city of San Francisco is a thriving city based on its design and embrace of implementing complete streets in their transportation planning. According to the San Francisco County Transportation Authority, “The City's Better Streets Plan provides guidance on designing streets that incorporate people first, considering pedestrians, bicyclists, transit, street trees, stormwater management, utilities, and livability as well as vehicular circulation and parking" (San Francisco County Transportation Authority, n.d.). This holistic view of planning their new roadways and improving existing ones provides the city with many benefits, such as economic vitality, improved safety, and healthier communities.

One of San Francisco's most successful methods for creating complete streets is utilizing road diets, which usually involves reducing the number of vehicle traffic lanes and repurposing that space for alternate travel modes. In his book, Schwartz notes that "San Francisco has completed the most road diet programs in the country-more than forty as of [2015]" (Schwartz \& Rosen, 2015). These streets, like Valencia Street and Market Street, were successfully slimmed down to provide more active transportation areas. Road diets are another important complete street initiative to consider in small towns and rural communities.

\section{Pasadena}

The city of Pasadena, California has a large coalition of residents who are pas- 
sionate about complete streets. In 2013, they formed the Pasadena Complete Streets Coalition (PCSC) after three residents were killed by vehicles while bicycling in the Pasadena area within one year. The PCSC is a powerhouse of support for inclusive transportation measures and they are known for doing two things well; creating bicycle networks (bicycle lanes and Roseways) and public outreach (Pasadena Complete Streets Coalition, n.d.a).

The PCSC has successfully created continuous bicycle travel by adding bicycle lanes to roadways and using what they call Roseways. Roseways are low-stress neighborhood streets (Pasadena Complete Streets Coalition, n.d.a). This initiative is similar to Japan, where roads are separated by speed, not type of travel. By creating maps connecting high demand destinations to local origins and utilizing existing slow speed roadways, a connected system of roadways can form safe and convenient bicycling for minimal investment. This is a terrific option for small towns which have limited budgets.

Additionally, the PCSC does a tremendous job garnering community support for their initiatives, which is achieved through social media outreach, including a dedicated website, Facebook page, and Twitter account. One example of a tool they use on their website is the "DonutTree Kaleculator" where residents can equate what using a mode other than personal vehicle would earn them from a donut perspective and what it would earn the environment in benefits. For example, if one were to enter the following data into the calculator:

Your round-trip mileage: 5

Your weight (lbs.) (optional, used to calculate calories): 200

Fuel efficiency of your car (mpg): 17

How you'll get there: Biking, leisurely pace $(<10 \mathrm{mph})$

Then selecting Donut Mode and pressing the Calculate button, one would learn that by opting for bicycling over driving a personal vehicle, one would earn 1.6 donuts, 42.8 tree days and $154 \%$ of daily recommended allowance of exercise. While this data isn't exact, it provides a way for the public to quantify the benefits of replacing their automobile for each trip they take. This can be very influential to those who want to improve their health or the environment (Pasadena Complete Streets Coalition, n.d.b).

The PCSC also is an active partner with many local and regional groups and agencies who share similar initiatives. Partners include the City of Pasadena Department of Transportation, Calbike (California Bicycle Coalition), California Walks, SafeRoutes Partnership and local neighborhoods such as the North Fair Oaks Empowerment Initiative (Pasadena Complete Streets Coalition, n.d.a). To be successful in any complete streets initiative, there must be proactive communication and collaborative team effort with stakeholders from all sides.

\section{Chicago}

In addition to Samuel Scwartz, there is another transportation visionary who is working to reduce our dependency on cars for travel. Gabe Klein, former Commissioner for the Chicago Department of Transportation, is on a mission to 
make our cities healthier and safer. While working in Chicago, Klein and his colleagues flipped conventional transportation priorities, making the pedestrian the first priority instead of cars. Klein's reasoning for this approach is as follows: "The pedestrian... is the indicator species of a healthy city, a sustainable city and economically viable city. And in New York they've studied this, and they found, that guess what, when you create a space where people want to be, what do they do? They go there. And when they go there, they spend money. So this is a pro-business strategy." (TEDxTalks, 2017).

To put pedestrians first, the city of Chicago implemented an arsenal of safety initiative, many of which are shown in Figure 10 below. When they were done, they reported a $35 \%$ and $58 \%$ decrease in injuries to all street users (Along $8^{\text {th }}$ and $9^{\text {th }}$ Avenues respectively). Not only were injuries decreased, but retail increased $49 \%$ along portions of $9^{\text {th }}$ Avenue. The correlation of business benefits to safety benefits is undeniable (TEDxTalks, 2017).

\section{Portland}

The City of Portland, Oregom started a road diet movement in 2009 when they took residential streets and converted them into "neighborhood greenways". These neighborhood greenways promoted traffic calming techniques such as traffic circles, curb extensions, and lane diverting, while increasing open drainage measures such as swales and providing vegetation to replace what once was impervious surfaces dedicated to vehicles (Goldberg, 2018). The Portland Bureau of Transportation (PBOT) now boasts over 90 miles of these neighborhood greenways.

Later in 2016, Portland adopted a formal action plan toward safety for the City entitled Vision Zero: Saving Lives with Safe Streets. Recently updated in the summer of 2019, this policy guides the City in its goal to increase safety. This action plan includes several complete streets initiatives with the hope of increasing safety of Portland residents and visitors.

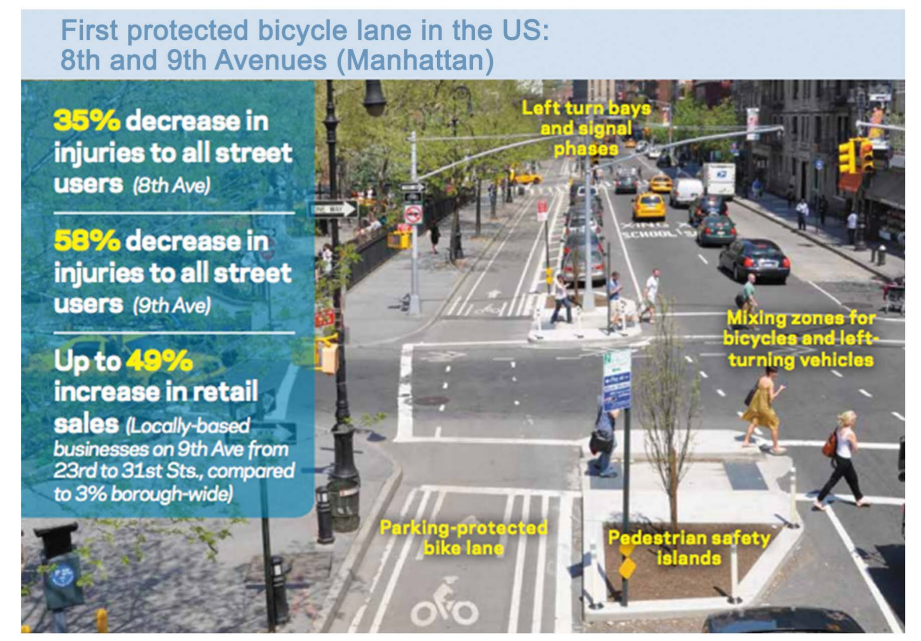

Figure 10. Active transportation improvements and associated statistics in Chicago (TEDxTalks, 2017). 
Another example of safe and complete streets implementation in Portland is the proposed Capitol Highway Complete Streets Project. This project, published in 2018 and updated in 2019, plans to convert an existing 4-lane roadway into a two-lane roadway with center turn lane. The proposed two-way left turn lane or TWLTL will provide vehicles a designated area to wait to turn while not blocking through traffic. The existing and proposed roadway cross sections are shown in Figure 11 below. By removing two travel lanes, which were historically plagued by stopped traffic waiting to turn left, the proposed design increases safety in several ways. The proposed design will reduce the swerving in and out of the through lane, increase the through lane widths, provide a buffer between the vehicular lanes and the bicycle lanes, provide a buffer between the parked cars and the bicycle lane, and provide a buffer between sidewalk and bicycle lane in one direction.

\section{Delaware}

In the State of Delaware, there has been immense progress towards complete streets. Most notably, in April of 2009, then Governor Jack A. Markell signed Executive Order Number 6 which directed the heads of all state departments and agencies to create a complete streets policy by September of that same year. The next year, DelDOT Secretary Carolann Wicks signed the finalized policy in January 2010 (DelDOT, 2010). According to DelDOT's Complete Streets Policy. 2010 and Beyond presentation, the key points of the Complete Streets Policy were as follows:

- Comprehensive, integrated and connected transportation network allowing choice.

- Accommodations for non-vehicular modes of transportation.

- All users considered in planning, designing, operating and maintaining roadways.

- Balance user needs to ensure solutions that enhance the community.

- Applicable to new and retrofit projects.

- Exemptions must be documented.

- Utilization of latest and best design standards.
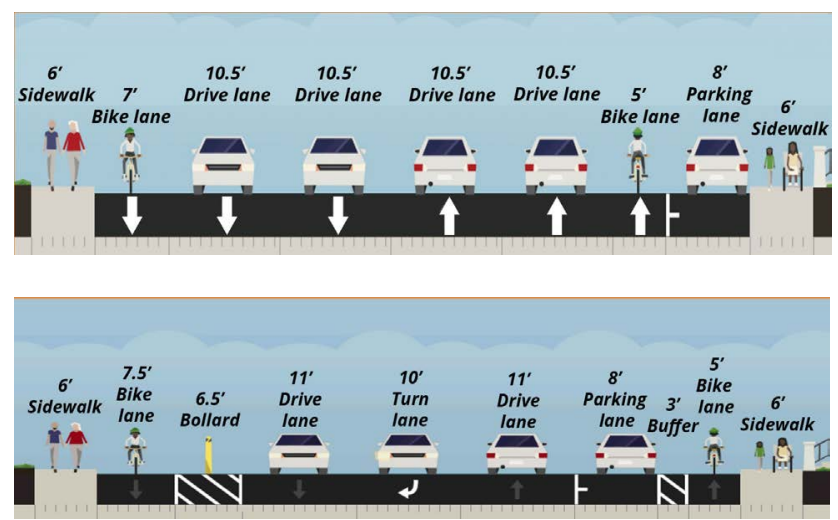

Figure 11. Existing and proposed capitol highway cross-sections (Portland Bureau of Transportation, 2019). 
Transportation planners and engineers in the state of Delaware also have an arsenal of literature and guidance at their disposal when designing complete streets and complete communities.

\section{Small Towns and Rural Areas}

When reviewing international and domestic examples of inclusivity in transportation modes, it is important to note that they do not all work in every location and there is no magic combination guaranteed to work in every location. Small towns in rural communities vary greatly from urban areas. The population and density are typically much lower, and the pace of life is generally slower. They typically have a small governing structure comprised of a mayor, town council and department heads (such as maintenance and police). Also, small towns usually do not have the resources by which to have a fulltime engineer or planner on staff to provide direction and design for transportation improvements.

The very nature of a rural community is that residents and guests travel in excess of $10-15$ minutes or more to do their commerce in the nearest town. Small rural towns often have the lowest rates of active transportation and are therefore prime locations for implementing complete streets to foster complete communities. The benefits include increasing safety, health, and potentially happiness, but how is this accomplished?

The shift for towns to be on board with investing their limited resources must hinge on the opportunity for economic development. To get participation from the residents of a town, they are going to want amenities that are both comfortable and connected. The complete streets must be comfortable to all users. This means they need to be safe, well lit, the correct size and dimensions for the intended use, and make everyone feel welcome. The complete streets must also be connected to the people, places and things we like to do or see or experience. A network of these streets should connect origins with destinations. Even if the user has to drive to get to town, once they arrive, they can leave the car and travel to all the locations they want comfortably by other means of travel. If people are comfortable and connected, they will want to return. If they return frequently, they will spend more money. And if they spend more money, the ripple effects spread to economic development for the area.

\subsection{Federal Guidance for Complete Streets}

Since complete streets have become more and more popular over the last decade, there has been a surge in the amount of documentation on the topic. Not only are there dedicated texts to the subject, but several federal documents reference elements of complete streets. The amount of information becomes difficult to compare. The United States Department of Transportation Federal Highway Administration created a guide to help condense the knowledge needed to understand multimodal design. The guide also provides a list of recommended references regarding complete streets. This reference manual was created specifi- 
cally for small towns and rural communities on implementing multimodal networks (FHWA, 2016).

The report focuses on potential solutions that can be implemented in a variety of settings. It takes into account the specific challenges of rural settings and organizes the content in a manner that allows readers to see which solutions work in different circumstances. The report notes that particular characteristics of small towns may differ, but they typically are comprised of residents who take longer trips for necessities, are less healthy overall, are less financially wealthy, and have higher crash rates than urban locations. The report also highlights an additional user in a complete street which hasn't been covered in many other resources, the horse drawn buggy and agricultural equipment. These are important transportation modes that must be considered when implementing complete streets in rural areas where they are prevalent.

The FHWA guide covers most multimodal options that can be designed to provide a transportation option to all users. The benefit of using this guide is it consistently specifies what locations each option would be well suited for by vehicle speed and volume, functional classification, and rural or built-up areas. Options covered include yield roadways, bicycle boulevards, advisory shoulders, paved shoulders, bike lanes, shared use paths, side paths, sidewalks, separated bike lanes, speed management (traffic calming) and other special network opportunities. Overall, the guide thoroughly describes each option and provides several visuals, common dimensions and provides a case study to review. This guide is a useful resource even to experienced transportation professionals as it clarifies the difference between similar multimodal facilities and provides condensed guidance on the design criteria.

\subsection{State Regulations for Small Towns}

For rapid nationwide adaptation of complete streets in small towns, it is very helpful if there are state regulations established by the Department of Transportation in each state. For example, in the state of Delaware, the Delaware Department of Transportation (DelDOT) enacted their complete streets policy in 2009 , in which they included important information and regulations on the implementation of multimodal facilities. Since DelDOT oversees the maintenance of over $90 \%$ of roads in the state of Delaware, the policy has been required over a majority of the state when new capital or private projects are proposed. Considering a multitude of regulations and guidance available, the University of Delaware's Institute for Public Administration created a resource guide specific to Delaware (Institute for Public Administration, 2011).

The Complete Streets in Delaware: A Guide for Local Governments document was designed to aid municipalities and counties in Delaware (Institute for Public Administration, 2011):

- Create safe and inviting road networks for all users.

- Transform a vision for complete streets into plans, policies, design stan- 
dards, and maintenance practices.

- Ensure that transportation facilities are constructed and maintained to ADA standards.

- Visualize how to balance the needs of all roadways users and transform existing roadways to complete streets.

If similar statewide complete streets policy regulations are established and more guides like the UD IPA guide are created, the process of implementing complete streets in small towns will be much smoother and more efficient.

\subsection{Small Town Complete Street Methods}

Although rural implementation of complete streets in the US is far behind the progress made in urban developments worldwide, recently, many states are finding methods to make roads in these smaller, isolated towns more accessible for all transportation modes. However, due to the low population density and greater distance between destination nodes in and around these areas, the methods that must be used in small, rural towns are slightly different than the concepts that work well in urban or suburban areas.

In Georgia, The Southern Georgia Regional Commission has published a document with many recommendations specific to the rural communities in that region. Their suggestions are tailored to the fact that rural areas in that region are mostly used for agriculture and that the roads experience low volume, but have high speed traffic (Southern Georgia Regional Commission, n.d.). Accordingly, because of travel distance between amenities and safety concerns, they do not recommend pedestrian infrastructure such as sidewalks. These sidewalks would be expensive and underused, and therefore ineffective. Instead, they suggest allowing opportunity for bicycling to increase transportation choice, as bicycling can still be viable for intermediate distances. However, a separate bike lane would be too expensive in these communities. Instead, and a safe and inexpensive alternative suggested is to widen road shoulders and use striping and signage to accommodate biking, as shown in Figure 12.

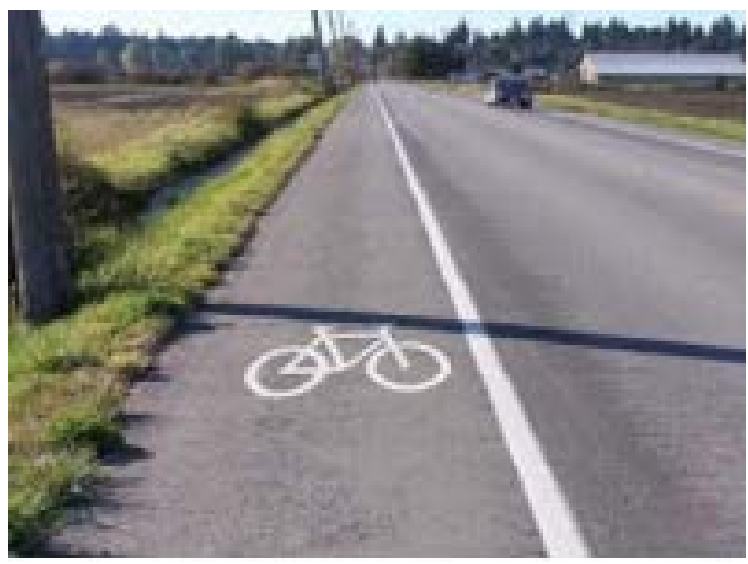

Figure 12. Shoulder biking accommodation on rural streets (Southern Georgia Regional Commission, n.d.). 
A design manual for Hampshire county in the state of Massachusetts echoes similar suggestions for rural communities and small towns in that area. They also suggest advisory bike lanes in the form of widened shoulders as a way to provide an active transportation alternative. However, they additionally suggest pedestrian facilities for walking options in residential developments and near schools in rural or agricultural areas. They suggest creating sidewalks in neighborhoods that have enough space and financial capability, but a more cost-friendly option includes a pedestrian lane with dividing striping, along with traffic calming measures that ensure pedestrian safety (Alta Planning \& Design, 2017). Another suggested option, specific to residential neighborhoods in rural or suburban areas, is creating narrower, shared use roads, where speed limits and other traffic calming techniques keep vehicles slow enough to maintain comfort for pedestrians and bicyclers.

Another great idea for rural towns was brought up in a study that attempted to increase physical activity in rural areas, as rural residents often have the lowest physical activity rates due to the limited active transportation infrastructure available. The findings of this study indicate that trails can significantly increase physical activity and provide an essential opportunity for active transportation for people who live in rural communities (Park, Eyler, Tabak, Valko, \& Brownson, 2017). The authors recommend that if the location permits, these trails should connect homes with recreational facilities and stores to allow more residents to choose active transportation modes for shorter trips in these rural towns. While the use of trails does not necessarily make streets more "complete", it does create greater transportation equity for different modes. Nonetheless, there are many challenges to creating these trails in small towns, most notably funding and limited resources.

\subsection{Small Town Implementation Process for Complete Streets}

From the international and domestic best practice examples noted, along with the small town/rural area methods discussed, there are several general recommendations one can follow when retrofitting completeness to an existing road network in a small town. When formulating a plan, generic enough for any small town to utilize, it is recommended to consult the UD IPA Complete Streets Implementation Checklist (Figure 13 below) and follow the following procedure:

1) Review the current Comprehensive Plan

\section{2) Communicate with Stakeholders}

a) Assess the Location/Destination hubs \& pathways

b) Determine the ownership and/or maintenance responsibility of the roadway

c) Assess the width of the existing rights-of-way

d) Determine funding and partnerships available

e) Perform surveys \& town hall meetings 


\begin{tabular}{|c|c|c|}
\hline \multicolumn{3}{|c|}{ IPA Complete Streets Implementation Check } \\
\hline Evaluate & Users & Modes \\
\hline \multicolumn{3}{|c|}{$\begin{array}{l}\text { Vision } \\
\text { reets that includes all users and modes of transportation? }\end{array}$} \\
\hline $\begin{array}{l}\text { Plans } \\
\text { Policies } \\
\square \text { Design Standards }\end{array}$ & $\begin{array}{ll} & \text { Olders Adults } \\
\text { ㅇoung Children } \\
\text { ․ Users with } \\
\text { Disabilities }\end{array}$ & $\begin{array}{ll}\square & \text { Pedestrians } \\
\square & \text { Bicyclists } \\
\square & \text { Transit Users } \\
\square & \text { Freight } \\
\square & \text { Motorists }\end{array}$ \\
\hline \multicolumn{3}{|c|}{$\begin{array}{l}\text { Planning } \\
\text { Do planning documents reflect complete streets principles that are inclusive of all users and modes of transportation? }\end{array}$} \\
\hline $\begin{array}{l}\text { Comprehensive Plan } \\
\text { Are goals, objectives, and comprehensive-plan elements } \\
\text { inclusive of all users and modes of transportation? }\end{array}$ & $\begin{array}{l}\text { Olders Adults } \\
\text { ㅁ Young Children } \\
\text { ㄴ Users with } \\
\text { Disabilities } \\
\end{array}$ & $\begin{array}{ll} & \text { Pedestrians } \\
\square & \text { Bicyclists } \\
\square & \text { Transit Users } \\
\square & \text { Motorists } \\
\end{array}$ \\
\hline $\begin{array}{l}\text { Official Map } \\
\text { Does the Official Map reflect transportation networks } \\
\text { that are inclusive of all users? }\end{array}$ & N/A & $\begin{array}{ll} & \text { Pedestrians } \\
\square & \text { Bicyclists } \\
\square & \text { Transit Users } \\
\square & \text { Motorists }\end{array}$ \\
\hline $\begin{array}{l}\text { C Capital-Im } \\
\text { Do short-and long } \\
\text { include access for } \\
\text { networks? }\end{array}$ & $\begin{array}{ll} & \text { Olders } \\
\square & \text { Young } \\
\square & \text { Users } \\
\text { Disabil } & \end{array}$ & $\begin{array}{ll}\square & \text { Pedestrians } \\
\square & \text { Bicyclists } \\
\square & \text { Transit Users } \\
\square & \text { Motorists } \\
\end{array}$ \\
\hline $\begin{array}{l}\text { Specific Plans } \\
\text { - Downtown Revitalization } \\
\text { - Trail Studies } \\
\text { - Circulation Plans } \\
\text { - ADA Transition Plan }\end{array}$ & 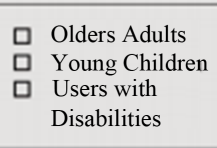 & $\begin{array}{l}\square \text { Pedestrians } \\
\square \text { Bicyclists } \\
\square \text { Transit Users } \\
\square \text { Motorists }\end{array}$ \\
\hline \multicolumn{3}{|c|}{$\begin{array}{l}\text { Policies } \\
\text { Are local government policies and regulations consistent with a state's complete streets policy? } \\
\text { Do policies reflect complete streets principles that are consistent with the local government's planning documents? }\end{array}$} \\
\hline $\begin{array}{l}\text { Subdivision Ordinances } \\
\text { ㄱoning Code Ordinances } \\
\text { ㄴnified Development Code } \\
\text { (Subdivision and Zoning regulations) }\end{array}$ & 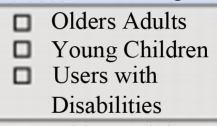 & $\begin{array}{ll}\square & \text { Pedestrians } \\
\square & \text { Bicyclists } \\
\square & \text { Transit Users } \\
\square \text { Motorists } \\
\end{array}$ \\
\hline $\begin{array}{l}\text { ADA Compliance } \\
\cdot \text { ADA Transition Plan }\end{array}$ & $\begin{array}{ll} & \text { Olders Adults } \\
\text { ㅁ Young Children } \\
\text { ㄴ Users with } \\
\text { Disabilities } \\
\end{array}$ & $\begin{array}{ll} & \text { Pedestrians } \\
\square & \text { Bicyclists } \\
\square & \text { Transit Users } \\
\square & \text { Motorists } \\
\end{array}$ \\
\hline \multicolumn{3}{|c|}{$\begin{array}{c}\text { Design Standards } \\
\text { Do design standards comply with federal, state, and local government requirements? }\end{array}$} \\
\hline $\begin{array}{l}\text { Design Standards } \\
\cdot \text { MUTCD · AASHTO • ADAAG } \\
\text { PROWAG } \cdot \text { DelDOT (for Delaware only) } \\
\cdot \text { Local Government Design Manuals }\end{array}$ & $\begin{array}{l}\text { ㅁ Olders Adults } \\
\text { ㅁ Young Children } \\
\text { ㄴ Users with } \\
\text { Disabilities }\end{array}$ & $\begin{array}{l}\text { ㅁ Pedestrians } \\
\square \text { Bicyclists } \\
\square \text { Transit Users } \\
\square \text { Motorists }\end{array}$ \\
\hline \multicolumn{3}{|c|}{$\begin{array}{l}\text { Facility Maintenance } \\
\text { Does the community meet ADA requirements for state and local governments to maintain accessible features in } \\
\text { "operable working condition?" }\end{array}$} \\
\hline $\begin{array}{l}\text { Local Government Ordinances } \\
\square \text { Public Works Policies and Preventative } \\
\text { Maintenance Schedules } \\
\text { Snow Removal Management Plans } \\
\text { M Municipal Maintenance Agreements }\end{array}$ & $\begin{array}{l}\text { O Olders Adults } \\
\text { ㅇoung Children } \\
\text { Users with } \\
\text { Disabilities }\end{array}$ & $\begin{array}{ll} & \\
\square & \text { Pedestrians } \\
\square \text { Bicyclists } \\
\square \text { Transit Users } \\
\square \text { Motorists }\end{array}$ \\
\hline
\end{tabular}

Figure 13. IPA complete streets implementation checklist (Institute for public administration, 2011).

\section{3) Implement appropriate complete streets strategies based on available} ROW and funding.

a) Prioritize ALL users

b) Designate no-vehicle plaza at downtown location

c) Invest in signing and striping

d) Research availability of public transport

e) Identify traffic calming measures that would function in all speed zones

f) Improve all areas for ADA accommodations

g) Classify streets by speed, not use

h) Identify ways to innovate and incentivize local business owners to provide 
public-private partnerships

i) Identify locations for road diets

4) Continue active communication with public.

5) Review all recommendations through the lens of safety.

The simple 5 step process above can be implemented and duplicated globally keeping in mind that all locations are unique and will have their own complexities. The steps above can be converted into a simplified flow chart for ease of reference. These tools form a framework of options to consider, but the enfaces of any project should be the communication and context sensitive nature of your design to fit into the landscape of the community.

\section{Conclusion}

The use of complete streets to combat an auto-centered transportation environment is becoming more and more widespread across the world. This method is one of the best ways to provide transportation equity and encourage active modes of travel, and research shows that this not only alleviates vehicle traffic from roads, but provides environmental, health, and safety benefits as well.

The present article has identified several key examples of successful complete street implementation across the world. A prime example is Amsterdam, Netherlands, where most roads are shared by all modes of travel, and their city design and culture incentivizes the use of bicycles, a far healthier and environmentally friendly alternative to automobiles. Their bicycle networks and infrastructure should be replicated all over the world. Another extremely successful method of providing transportation equity was observed in Tokyo, Japan, where streets are divided by speed, allowing the opportunity for many transportation modes depending on the route one takes to their destination. This method should be used wherever there is not enough street space to allow separate lanes for all modes of travel. There are many other notable international examples of complete streets or greater travel mode choice.

While the US is certainly behind its international counterparts with respect to complete streets and travel by active transportation modes such as walking and biking, we are certainly making progress in several big cities. For example, the use of road diets has been very successful in cities like San Francisco and Portland. We have also begun investing in bicycle networks in some cities, such as Pasadena, where they have created many bicycle lanes and low speed Roseways. In Chicago, planners began prioritizing the pedestrian in street design, which saw significant safety and economic improvements.

Complete streets have been successful in urban settings, but we must not forget isolated small towns and rural areas. These places often have the lowest transportation equity and financial resources, making complete streets implementation in rural areas much more challenging. Nevertheless, it is not impossible, and many ideas have been presented regarding the planning and creation of complete streets in these areas. A few examples of methods that work in urban 
settings, but must be modified for rural settings, is provided, along with new ideas which could provide opportunities for active transportation in these places. Finally, a step-by-step process for implementing complete streets in small towns is described. Thus, the main contributions of this article can be summarized in three important and inter-related topics: 1) collecting and reporting examples of successful international complete street designs, 2) collecting and reporting examples of successful national (USA) complete street designs, and 3) reporting the most important methods for implementation of complete street designs in small towns and rural areas.

Of course, there are many areas that require additional research for the implementation of complete streets. Transportation planners and engineers must perform more studies to quantify the economic, environmental, and health effects of using different complete streets methods to identify which methods are most successful depending on the setting. Additionally, much more planning is necessary to find ways for funding complete street initiatives in small towns. With greater focus on these areas, we can design a transportation environment that provides much greater transportation equity to residents in all settings.

\section{Conflicts of Interest}

The authors declare no conflicts of interest regarding the publication of this paper.

\section{References}

Alta Planning \& Design (2017). Urban, Rural and Suburban Complete Streets Design Manual for the City of Northampton and Communities in Hampshire County [Report]. http://www.northamptonma.gov/DocumentCenter/View/6668/Hampshire-County-Co mplete-Streets-Design-Manual_1-4-2017-FINAL?bidId

Brasor, P. (2016). Accommodating Disabilities, But Only within Reason. The Japan Times. https://www.japantimes.co.jp/news/2016/04/16/national/media-national/accommodati ng-disabilities-within-reason

Buehler, R., \& Pucher, J. (2012). Walking and Cycling in Western Europe and the United States: Trends, Policies, and Lessons (PP. 34-42). TR News 280 (May June). http://onlinepubs.trb.org/onlinepubs/trnews/trnews280WesternEurope.pdf

Calloway, D. M. (2018). Bicycle Parking near Amsterdam Central Train Station [Photograph].

City Clock Magazine (2013). Strøget Pedestrian Street (Copenhagen) [Photograph]. https://www.flickr.com/photos/118304891@N02/13298255555

DelDOT (2010) Complete Streets Policy: 2010 and Beyond. [PowerPoint] Slide 3. https://www.bidenschool.udel.edu/ipa/content-sub-site/Documents/DelDOTComplete Streets_web.pdf

Dylanagonzales2011 (2019). Online Image. https://pixabay.com/photos/tokyo-street-photography-japan-road-4503492

European Commission Directorate-General for the Environment (2004). Reclaiming City Streets for People: Chaos or Quality of Life? Luxembourg: Publications Office of the EU. https://op.europa.eu/en/publication-detail/-/publication/94a8a003-be86-467a-9a85-63a $\underline{5 \mathrm{~d} 52 \mathrm{bf} 7 \mathrm{ae}}$ 
FHWA (Federal Highway Administration) (2009). Speed Concepts: Informational Guide. US DOT. https://safety.fhwa.dot.gov/speedmgt/ref_mats/fhwasa10001

FHWA (Federal Highway Administration) (2016). Small Town and Rural Multimodal Networks [Report]. http://www.fhwa.dot.gov/environment/bicycle_pedestrian

Goldberg, D. (2018). Portland's Street Design Experimentation Creates a Redrawn Paradigm. Seattle, DC: Sightline Institute.

https://www.sightline.org/2018/08/09/portland-street-design-complete-streets-greenways

Google (n.d.a). Map of Kanaalstraat in Lisse, Netherlands.

Google (n.d.b). Street View of Kanaalstraat in Lisse, Netherlands.

Institute for Public Administration-University of Delaware (2011). Complete Streets in Delaware: A Guide for Local Governments [Report].

https://cpb-us-w2.wpmucdn.com/sites.udel.edu/dist/a/390/files/2013/12/CompleteStre etsGuide-web-2h5fl32.pdf

Kingsbury, K., Lowry, M., \& Dixon, M. (2011). What Makes a “Complete Street" Complete? Transportation Research Record: Journal of the Transportation Research Board, 2245, 103-110. https://doi.org/10.3141/2245-13

Kodransky, M. (n.d.). Complete Streets. 2030 Palette. http://www.2030palette.org/complete-streets

Li, Y., Wang, W., Wang, J. et al. (2011). Impact of Air Pollution Control Measures and Weather Conditions on Asthma during the 2008 Summer Olympic Games in Beijing. International Journal of Biometeorology, 55, 547-554. https://doi.org/10.1007/s00484-010-0373-6

McCann, B. (2010). Complete Streets Lessons from Copenhagen. Smart Growth America. https://smartgrowthamerica.org/complete-streets-lessons-from-copenhagen/

National Household Travel Survey (2017). Number of Person Miles of Travel (PMT) by Household Income [Graph]. https://nhts.ornl.gov/person-miles

Park, T., Eyler, A., Tabak, R., Valko, C., \& Brownson, R. (2017). Opportunities for Promoting Physical Activity in Rural Communities by Understanding the Interests and Values of Community Members. Journal of Environmental and Public Health, 2017, Article ID: 8608432. https://doi.org/10.1155/2017/8608432

Pasadena Complete Streets Coalition (n.d.a). Our Story: The Pasadena Complete Streets Coalition. https://www.pasadenacsc.org/about-us

Pasadena Complete Streets Coalition (n.d.b). https://www.pasadenacsc.org/donut

Portland Bureau of Transportation (2019). Vision Zero: Saving Lives with Safe Streets. https://www.portlandoregon.gov/transportation/article/734631

Price, A. (2019). Lessons from the Streets of Tokyo. Strong Towns. https://www.strongtowns.org/journal/2019/10/1/lessons-from-the-streets-of-tokyo

Project for Public Spaces (2015). Case Studies: Great Public Spaces-Stroget. https://www.pps.org/places/stroget

San Francisco County Transportation Authority (n.d.). Complete Streets. https://www.sfcta.org/policies/complete-streets

Schwartz, S. I., \& Rosen, W. (2015). Street Smart: The Rise of Cities and the Fall of Cars. New York: Public Affairs.

Smart Growth America (n.d.). National Complete Streets Coalition. https://smartgrowthamerica.org/program/national-complete-streets-coalition 
Southern Georgia Regional Commission (n.d.). Best Practices for Complete Streets in Rural Communities [Report].

https://www.sgrc.us/documents/bicycle/4fe40511bac13ad56d70bbde55e0e6fb.pdf

TEDxTalks (2014). The Happy City Experiment/Charles Montgomery/TEDxVancouver [Video]. YouTube. https://www.youtube.com/watch?v=7WiQUzOnA5w

TEDxTalks (2015). Architect's Hands: How Can We Design Better Streets/Evelina Ozola/TEDxRiga [Video]. YouTube. https://www.youtube.com/watch?v=8iQnrM3DkVI

TEDxTalks (2017). Cars Almost Killed Our Cities, But Here's How We Can Bring Them Back/Gabe Klein/TEDxMidAtlantic [Video]. YouTube. https://www.youtube.com/watch?v=GXn2Iu8mSWY

University of Minnesota (2017). Happiness: A New Way to Measure Transportation Systems. Catalyst: Accelerating the Pace of Transportation Innovation. http://www.cts.umn.edu/publications/catalyst/2017/november/happiness

Wright, P. H., Ashford, N. J., \& Stammer, R. J. (1998). Transportation Engineering: Planning and Design (4th ed.). Hoboken, NJ: John Wiley and Sons.

Zehngebot, C., \& Peiser, R. (2014). Complete Streets Come of Age. Chicago, IL: American Planning Association.

https://www.planning.org/planning/2014/may/completestreets.htm

Zurich Tourism (n.d.). Local Public Transportation.

https://www.zuerich.com/en/visit/getting-around-in-zurich/public-transport-in-zuerich 